\title{
Genetic Resistance to Infectious Diseases in the Era of Personalized Medicine
}

\author{
Andrei Alimov* \\ Research Centre for Medical Genetics, Russia \\ *Corresponding author: Andrei Alimov, Research Centre for Medical Genetics, 115478 Moscow, Moskvorechie str, 1, Russian Federation, Russia
}

Submission: 眥: October 22, 2018; Published: 眥 October 25, 2018

\section{Opinion}

Individual particularities of resistance to pathogens have been the focus of clinicians and researchers for centuries. Several theories and concepts were formulated to explain this phenomenon. They include the immunological theory of infectious diseases, the genetic theory of infectious diseases, the concept of latent and asymptomatic infection, monogenic and polygenic type of inheritance of resistance to pathogens and a number of others [1]. Nowadays, most of these concepts are reflected in the modern theory called "A Unified Genetic theory of infection disease". The theory assumes that at an early age susceptibility to pathogenic microorganisms is caused by inherited variants of genes, while in adults features of a disease course depend on the total action of several genetic loci. In elderly people, a special role in the initiation and development of infectious disease plays somatic mutations [2]. In this regard, recently developed methodological approaches to wide genome analysis allow us to hope for a significant expansion of our understanding of genetic resistance to infectious diseases at both individual and population levels.

In recent decades, significant progress has been made in the study of genetic resistance to the pathogens of the genus Mycobacterium: M. tuberculosis (causes tuberculosis), M. leprosy (causes leprosy), and M. ulcerans (causes Buruliulcer). The collected data clearly demonstrate the polygenic nature of resistance to these diseases, which is important for creating a strategy for monitoring resistance/susceptibility to these infections within the framework of personalized medicine concept [3].

Another large series of studies is linked to immunity to P. Falciparum, which causes malaria. It was shown that some loss of function mutations provide resistance. Such mutations are displayed in genes: $\alpha$-globin, $\beta$-globin, Glucose-6-phosphate dehydrogenase, Duffy antigen/chemokine receptor, ABO transferase, HLA-B. According to modern estimates, most genes have mutated centuries ago. Mutations were common in several populations [4].

Resistance to viral diseases is also actively studied. A number of intracellular mechanisms ensuring resistance to viral infections have been identified [5]. Mutations which provide immunity to human immunodeficiency virus [6], parvovirus B19 [7], norovirus [8] are well known.

Research on model animals is of great importance for understanding the genetic mechanisms of predisposition to infectious diseases. The genetic law of homologous series suggests that mutations and molecular mechanisms found on animal models may exist in humans too. Recently, a new mechanism of resistance to pathogens of the genus Salmonella has been identified on the model of Mus musculu. The mechanism is based on the interaction between the subtypes of T- and B-lymphocytes [9]. Genetic resistance of Sus domesticus to enterotoxigenic F18+ E. coli infections is also well-known. The allelic variant of the FUT1 gene encoding fucosyltransferase provide the resistance [10]. In recent years significant progress has been made in the study of resistance to transmissible spongiform encephalopathies of Capra hircus [11]. The alleles of resistance to avian leukemia virus was mapped for Gallus gallus domesticus [12]. New achievements in this area are steadily growing.

Thus, it is no doubt that an important direction of modern genetics of infectious diseases is the search for allelic variants of genes that provide resistance/ susceptibility to pathogens. These studies should combine both advances in human molecular genetics and comparative analysis of resistance to pathogens of other species. Only joint efforts of all specialists in this field: clinicians, microbiologists, geneticists and bioinformatics will make it possible to create individual maps of resistance/predisposition to pathogens for humans. The creation of such maps is a part of the personalized medicine of the future.

\section{References}

1. Alcaïs A, Abel L, Casanova J-L (2009) Human genetics of infectious diseases: between proof of principle and paradigm. J Clin Invest 119(9): 2506-2514.

2. Casanova J-L, Abel L (2013) The genetic theory of infectious diseases: A brief history and selected illustrations. Annu Rev Genomics Hum Genet 14: 215-243.

3. Dallmann-Sauer M, Correa-Macedo W, Schurr E (2018) Human genetics of mycobacterial disease. Mamm Genome 29(7): 523-538. 
4. Hedrick PW (2011) Population genetics of malaria resistance in humans. Heredity 107(4): 283-304.

5. Beutler B, Eidenschenk C, Crozat K, Imler JL, Takeuchi O, et al. (2007) Genetic analysis of resistance to viral infection. Nat Rev Immunol 7: 753766.

6. Kaur G, Mehra N (2009) Genetic determinants of HIV-1 infection and progression to aids: susceptibility to hiv infection. Tissue Antigens 73: 289-301.

7. Brown KE, Hibbs JR, Gallinella G, Anderson SM, Lehman ED, et al. (1994) Resistance to parvovirus b19 infection due to lack of virus receptor (erythrocyte p antigen). N Engl J Med 330(17): 1192-1196.

8. Le Pendu J, Ruvoen-Clouet N, Kindberg E, Svensson L (2006) Mendelian resistance to human norovirus infections. Semin Immunol 18: 375-386.
9. Griffin AJ, McSorley SJ (2011) Development of protective immunity to salmonella, a mucosal pathogen with a systemic agenda. Mucosal immunology 4(4): 371-382.

10. Coddens A, Verdonck F, Mulinge M, Goyvaerts E, Miry C, Goddeeris B, et al. (2008) The possibility of positive selection for both F18 + Escherichia coli and stress resistant pigs opens new perspectives for pig breeding. Vet Microbiol 126: 210-215.

11. EFSA BIOHAZ Panel, Ricci A, Allende A, Bolton D, et al. (2017) Scientific opinion on genetic resistance to Transmissible Spongiform Encephalopathies (TSE) in goats. EFSA Journal 15(8): 4962.

12. Li X, Chen W, Zhang H, Li A, Shu D, et al. (2018) Naturally occurring frameshift mutations in the tvb receptor gene are responsible for decreased susceptibility of chicken to infection with avian leukosis virus subgroups B, D, and E. J Virol 92(8): e01770-17.

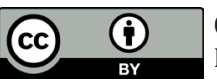

Creative Commons Attribution 4.0

International License

For possible submissions Click Here
Submit Article

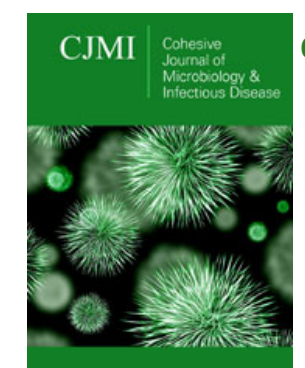

Cohesive Journal of Microbiology \& Infectious Disease

\section{Benefits of Publishing with us}

- High-level peer review and editorial services

- Freely accessible online immediately upon publication

- Authors retain the copyright to their work

- Licensing it under a Creative Commons license

- Visibility through different online platforms 